\title{
Occurrence and Distribution of Coconut Diseases in Tamil Nadu, India
}

\author{
E. Rajeswari $^{1 *}$, R. Ramjegathesh ${ }^{2}$, V. Sivakumar ${ }^{1}$, S. Praneetha ${ }^{1}$, \\ L. Pugalendhi ${ }^{3}$ and H. P. Maheswarappa ${ }^{4}$
}

${ }^{1}$ Coconut Research Station, Tamil Nadu Agricultural University, Aliyarnagar, India

${ }^{2}$ Rice Research Station, Tamil Nadu Agricultural University, Ambasamuthiram, India

${ }^{3}$ Horticultural College and Research Institute, Tamil Nadu Agricultural University, Coimbatore, India

${ }^{4}$ ICAR, Central Plantation Crops Research Institute, Kasaragod, Kerala, India

*Corresponding author

\section{A B S T R A C T}

\section{Keywords}

Coconut, Bud rot, Basal stem rot, Leaf blight, Root (wilt), Survey

Article Info

Accepted: 25 September 2020 Available Online: 10 October 2020
Coconut is an important plantation crop with many decades of life span ,suffers from numerous diseases incited by fungi ,bacteria, virus, viriod and phytoplasma leads to drastic reduction in yield. Roving survey was conducted in five major coconut growing districts of Tamil Nadu viz., Coimbatore, Tirupur, Theni, Tirunelveli and Kanyakumari districts during 2014- 2019 for assessing the incidence of important diseases of coconut .The fungal diseases viz., bud rot, basal stem rot, stem bleeding, leaf blight and leaf spot and phytoplasma disease viz., root (wilt) are the widely prevalent disease in these districts. The highest bud rot incidence of $7.7 \%$ was observed in Pongalliyoor village in Coimbatore district and basal stem rot incidence $(35.29 \%)$ in Manupatti village, Tirupur district . The prevalence of stem bleeding was found to be sporadic and the high incidence of $12.0 \%$ was observed in Therichanamkoppu village, Kanyakumari district. The highest mean district incidence of bud rot, basal stem rot and stem bleeding was registered in Tirupur district which were $1.40 \%, 2.59 \%$ and $4.94 \%$ respectively. The severity of leaf blight was more (32.0 PDI) in Thanthoni, village, Tirupur district and the leaf spot (25. 5 PDI) in Kaliapuram village, Coimbatore district and the district mean incidence of leaf blight was highest (20.19 PDI) in Tirupur district and leaf spot (10.1 PDI) in Theni district. The maximum incidence $(37.25 \%$ ) of root (wilt) was noted in Gudalore village, Theni district and the district wise average was high $(21.1 \%)$ in Theni district. The state average of the surveyed district for bud rot, basal stem rot, stem bleeding, leaf blight, leaf spot and root (wilt) incidence ranged from $0.09-0.60 \%, 0.44-1.03 \%, 0.1-1.05 \% 4.9-8.52$ PDI, 2.55 to $6.55 \mathrm{PDI}$ and $5.6-10.3 \%$ respectively.

\section{Introduction}

Coconut (Cocos nucifera Linn.) is an important plantation and perennial oil seed crop of India. It is called as Kalpavriksha or
Tree of Heaven or tree of Abundance, because each and every part of the coconut is useful to human being. Coconut farming offers livelihood security to millions of people across India and it provides improved 
nutrition, employment and income generation as well. It supplies raw materials for coir industry and coconut shell is a good source of activated carbon. India is a primary coconut producing country with a production of 21288 million nuts from an area of 2150.89 thousand hectares with the productivity of 9897 nuts per hectare (CDB, 2018).

Though coconut palm is hardy in nature and adaptable to varied climatic conditions is affected by many diseases at various phases of its growth starting from seedlings to bearing stage (Hentry Louis, 2002). Among the diseases bud rot (Phytophthora palmivora), Thanjore Wilt (or) basal stem rot (Ganoderma lucidum), stem bleeding disease (Thievolopsis paradoxa) leaf blight (Lasiodiplodia theobromae) and root wilt. (Candidatus phytoplasma) are the major diseases of coconut in India (Snehalatharani, 2016). Yield loss up to $10 \%$ and $13 \%$ was reported due to bud rot and basal stem rotrespectively (Nambiar and Rawther, 1993). Leaf blight and root wilt inflicts s yield loss ranged from $10-25 \%$ and $35-80 \%$ respectively (Jhonson et al., 2014, Ramjagatheh et al., 2019). The most e effective surveillance in plant health is highly imperative because of emergence of new pathogens and strains. Periodical survey on disease incidence helps to assess the general health of the palm, identification of hotspot area for a particular disease, developing forewarning disease models and to devise suitable management strategy.

Systematic measure on the intensity of diseases in different agro-ecological zone is foremost important to provide technical and official support to the farmers to prevent yield loss in coconut (Chandran et al., 2017).With this in view the present investigation was carried out with a objective of assessing the occurrence and distribution of important diseases in major coconut growing districts of Tamil Nadu and to identify the endemic or hot spot area.

\section{Materials and Methods}

Roving survey was carried out in five districts of Tamil Nadu viz., Coimbatore, Tirupur, Theni and Tirunelveli for the five years from 2014- 2019 (Figure 1) to assess the incidence of major diseases of coconut. In each district five blocks were selected and from each block seven villages comprising of 10 garden with minimum of 75 palms/ garden. From 75 palms 25 palms were selected randomly for assessing the disease incidence. A total of 175 villages were covered for each year. The diseases viz., bud rot, basal stem rot and stem bleeding and root (wilt) incidences were assessed in terms of percentage. The observation recorded on disease incidence based on expression of characteristic symptoms of the respective disease. The per cent disease incidence was calculated using the formula

Per cent disease incidence $=\frac{\text { Number of infected plants }}{\text { Total number of plants }} \times 100$

The foliar diseases viz., leaf blight and leaf spot were assessed by grading the individual leaflets. Twenty five leaflets from the lower 10 leaves in each palm selected at random and the disease was scored based on a score chart of $0-5$ scale

\begin{tabular}{|l|l|l|}
\hline $\mathbf{0}$ & - & No infection \\
\hline $\mathbf{1}$ & - & $<10 \%$ \\
\hline $\mathbf{2}$ & - & $11-25 \%$ \\
\hline $\mathbf{3}$ & - & $26-50 \%$ \\
\hline $\mathbf{4}$ & - & $51-75 \%$ \\
\hline $\mathbf{5}$ & & $>75 \%$ leaf area infected \\
\hline
\end{tabular}

The per cent disease Index (PDI) was calculated based on the formula PDI $=($ Sum of numerical ratings/ Total number of leaves observed $) \times(100 /$ Maximum disease grade $)$. 


\section{Results and Discussion}

\section{Bud rot}

Bud rot incited by Phytophthora palmivora causes rotting of spindle leaves and emits foul smell. Under favourable environmental condition the pathogen produces whitish fungal coating on the infected portion and secondary infection also occurs due to insect larvae The central shoot comes off easily on slight pulling as the basal portion is dead Fig $2 \mathrm{a}, 2 \mathrm{~b}, 2 \mathrm{c}$ and $2 \mathrm{~d}$.

Bud rot incidence was not observed in all the villages surveyed. The epidemic occurrence of disease was recorded during October to December especially in young palms of below 10 years old. The incidence of bud rot in individual coconut garden ranged from 0.0 7. $7 \%$ and the highest incidence of $7.7 \%$ per cent was observed in Pongalliyoor village of Anamalai block during 2018 to 2019. In the village viz., Ammapettai, Bodinayakanur block, Theni district bud rot incidence of 6.15 $\%$ was recorded (Table 1). The mean district incidence of bud rot in Coimbatore district varied between $0.01-1.01$ percent and the high incidence $(1.01 \%)$ was recorded during 2018- 19. In Tirupur district the incidence ranged from 0.11 - 1.40 per cent and more incidence 1.40 percent was observed during 2015-16 and in Theni, Tirunelveli and Kanyakuamari districts, average incidence of below one per cent was observed in all the five years of disease assessment (Table 2). The analysis of state average of the surveyed districts in Tamil Nadu revealed the mean incidence of bud rot was found to be more $(0.60 \%)$ during 2018 - 19 and it was low (.0.09\%) during 2014- 15 (Table 5).This finding was supported by several studies. High incidence of bud rot disease was noted in Kuttiyadi area of Kozhikode (Prabha and ChadraMohanan, 2009). Sharadraj and ChandraMohanan (2013) observed severe incidence of bud rot in four districts viz., Kasaragod, Kannur, Kozhikode and Wayanad, sporadic incidence in Coimbatore district of Tamil Nadu moderate level in East Godavari district of Andhra Pradesh. High rainfall, low temperature, high relative humidity and heavy circulating wind are favourable for the development and spread of the disease (Chandra Mohanan et al., 2008)

\section{Basal stem rot}

The causal agent of the disease is identified as Ganodermalucidum. The infected palms exhibits yellowing, withering and drooping of the outer fronds. Reddish brown bleeding patches observed near the base of the trunk through cracks up to 3-5 meters height. Fruiting body (bracket) along the side of the basal trunk (Figure 3a, b, c, d) .

Basal stem rot infection was mainly seen in the poorly maintained coconut garden. The results of the survey indicated that severe incidence was recorded in villages viz., Manupatti (35.29\%), Erippalayam (25.17\%), Udumalaipet block of Tirupur district (Table 1). The maximum district average of basal stem rot was observed in Tirupur district during 2014-15(2.59\%), 2015-16 (1.4\%), $2016-17(0.99 \%)$ and $2017-18(1.0 \%)$ and in Coimbatore district (1.45\%)during 201819(Table 2). In Tamil Nadu, the state average of 1.03 per cent incidence was registered during $2014-15$ and it was only 0.44 per cent during 2016 - 17(Table 5). The disease was found to bea major limiting factor in coastal districts of Tamil Nadu and Andhra Pradesh (Srinivasulu 2001a). Bhaskaran and Ramanathan (1984) observed incidence more incidence of basal stem rot in Thanjavur district followed by Chingelput district and the incidence ranged from 0.6 to $4.9 \%$ and in severely infected gardens, the disease incidence was as high as $31.4 \%$. Snehalatharani et al., (2014a) assessed 
occurrence of the disease during 2010-15 in different districts of Andhra Pradesh, Karnataka and Tamil Nadu and found the disease was major threat to coconut growers in all the three districts.. In Tamil Nadu, the maximum mean district incidence of $(6.5 \%)$ was recorded in Thanjavur district followed by Nagapattinam and Thiruvarur.

\section{Stem bleeding}

The causal organism of the disease is Ceratocystis paradoxa. The characteristic symptoms are exudation of reddish brown fluid from the cracks in the stem. Fluid trickles down to several feet on the stem and the exudates dries up forming a black crust (Figure 4) .

Stem bleeding incidence was not prevalent in all the villages and it was found to occur in a sporadic manner. From this survey the villages viz., Therichanamkoppu, Kanyakumari district Gudimangalam, Tirupur district were identified as a endemic area which registered the incidence of 12.0 and 10.80 per cent respectively(Table.1).The analysis of results on district average revealed that stem bleeding incidence was found to be high in Tirupur district during 2014-15 201516, 2017-18 and in Kanyakumari district during 2016-17 and 2018 -19(Table 2).In Tamil Nadu state average ranged from 0.1 1.05 per cent (Table 5).Stem bleeding of coconut is known to occur in nearly all the countries which grow coconut (Ohler, 1964) and serious infection was found to lead to reduced yield (Nambiar \& Sastry, 1988). Wounds, poor drainage, formation of hard laterite pan leading to crippled root growth, imbalanced mineral nutrition are other predisposing factors (Sulladmath and Shantappa, 1980). The disease has been found to occur in all soil types, but more in laterite soils and sandy soils on seashore or backwater areas (Nambiar, 1994).

\section{Leaf blight}

The disease is incited by Lasiodiplodia theobromae (Syn: Botryodiplodia theobromae) (Pat.) Symptoms are more conspicuous on lower fronds. The affected fronds, leaflets showed drying from tip downwards and exhibits a charred or burnt appearance leads to the reduction in photosynthesis.

Dark grey to brown lesions with wavy to undulated margins appear from the apex of the nuts. The fungus entered in to the kernel through mesocarp, resulting in a decay of the endosperm. The affected nuts were desiccated, shrunken, deformed and dropped prematurely (Figure $5 \mathrm{a}, \mathrm{b}$ ) .

Leaf blight incidence was found to widely prevalent in all the villages of Coimbatore, Tirupur and Dindigul districts and the severity of the disease was comparatively low in Tirunelveli and Kanyakumari districts. In this survey Thanthoni, Sencherimaali and Karapadi of Tirupur district and Odayakulam and Kaliapuram villages of Coimbatore district were found to be endemic location for the disease (Table 1).

The highest district average of leaf blight incidence was recorded in Coimbatore district during 2017-18 (7.88 PDI)and 2018-19(12.76 PDI) and in Tirupur district during 2014-15 (20.19 PDI),2015-16(10.25 PDI) and 2016-17 (10. 19 PDI) (Figure 8). The state average of 8.52 PDI was registered during 2014-15 and it was declined to 4.9 PDI during 2017- 18 and again increased to 7.24 PDI during 2018 - 19 (Table 5).Similar results were reported by Jonson et al., 2017 who reported that leaf blight is an emerging problem in Tamil Nadu and in recent years the disease is the spreading at a faster rate in Coimbatore, Erode, Dindigul and other districts of Tamil Nadu. 
Table.1 Endemic locations identified for various coconut diseases in Tamil Nadu

\begin{tabular}{|c|c|c|c|c|c|c|}
\hline \multirow[t]{2}{*}{ S.No } & \multirow[t]{2}{*}{ Disease } & \multirow[t]{2}{*}{ Year } & \multicolumn{3}{|c|}{ Endemic location } & \multirow{2}{*}{$\begin{array}{l}\text { DI/ } \\
\text { PDI }\end{array}$} \\
\hline & & & District & Blocks & Villages & \\
\hline \multirow[t]{5}{*}{1.} & \multirow[t]{5}{*}{ Bud rot } & 2014- 15 & Theni & Bodinayakanur & Ammapettai & 6.15 \\
\hline & & $2015-16$ & Tirupur & Udumalaipet & Pukkulam & 4.68 \\
\hline & & 2016- 17 & Tirupur & Pongalur & Kattur village & 5.73 \\
\hline & & $2017-18$ & Tirupur & Udumalaipeti & Mukonam & 5.06 \\
\hline & & $2018-19$ & Coimbatore & Anamaali & Pongalliyoor & 7.70 \\
\hline \multirow[t]{5}{*}{2.} & \multirow{5}{*}{$\begin{array}{l}\text { Basal } \\
\text { stem rot }\end{array}$} & 2014- 15 & Tirupur & Udumalaipet & Manupatti & 35.29 \\
\hline & & $2015-16$ & Tirupur & Sultanpet & Vadavedampatti & 12.00 \\
\hline & & 2016- 17 & Tirupur & Udumalaipet & Erippalayam & 25.17 \\
\hline & & $2017-18$ & Tirupur & Sultanpet & Odakkalpalayam & 12.0 \\
\hline & & $2018-19$ & Kanyakumari & Thovalai & Therichananamkoppu & 12.0 \\
\hline \multirow[t]{5}{*}{3.} & \multirow{5}{*}{$\begin{array}{l}\text { Stem } \\
\text { bleeding }\end{array}$} & 2014- 15 & Tirupur & Gudimangalam & Gudimanagalam & 10.80 \\
\hline & & $2015-16$ & Tirupur & Sulthanpettai & Odayakulam & 3.54 \\
\hline & & 2016- 17 & Tirupur & Pongalur & Karunkalipalayam & 2.24 \\
\hline & & $2017-18$ & Tirupur & Sultanpet & Vadavedampatti & 4.80 \\
\hline & & $2018-19$ & Kanyakumari & Thovalai & Therichananamkoppu & 12.00 \\
\hline \multirow[t]{5}{*}{4.} & \multirow{5}{*}{$\begin{array}{l}\text { Leaf } \\
\text { blight }\end{array}$} & 2014- 15 & Tirupur & Dharapuram & Thanthoni & 32.00 \\
\hline & & $2015-16$ & Tirupur & Udumalai & Sencherimalai & 26.45 \\
\hline & & 2016- 17 & Tirupur & Gudimangalam & Karapatti & 29.52 \\
\hline & & $2017-18$ & Coimbatore & Anamalai & Odayakulam & 26.0 \\
\hline & & $2018-19$ & Coimbatore & Anamalai & Kaliapuram & 25.5 \\
\hline \multirow[t]{5}{*}{5.} & \multirow[t]{5}{*}{ Leaf spot } & 2014- 15 & Coimbatore & Anamalai & Avalchinampalayam & 15.0 \\
\hline & & $2015-16$ & Coimbatore & Anamalai & Aathupollachi & 13.45 \\
\hline & & 2016- 17 & Coimbatore & Anamalai & Angalakuruch & 16.58 \\
\hline & & $2017-18$ & Coimbatore & Pollachi North & Velliagoundanur & 16.0 \\
\hline & & $2018-19$ & Coimbatore & Anamalai & Kalliyapuram & 25.4 \\
\hline \multirow[t]{5}{*}{6.} & \multirow{5}{*}{$\begin{array}{l}\text { Root } \\
\text { ( wilt) }\end{array}$} & 2014- 15 & Theni & Cumbum & Gudalore & 25.28 \\
\hline & & $2015-16$ & Theni & Cumbum & Gudalore & 30.00 \\
\hline & & 2016- 17 & Theni & Cumbum & Gudalore & 34.70 \\
\hline & & $2017-18$ & Theni & Cumbum & Gudalore & 35.0 \\
\hline & & $2018-19$ & Theni & Cumbum & Gudalore & 37.25 \\
\hline
\end{tabular}

Table.2 Incidence of coconut bud rot in different districts of Tamil Nadu

\begin{tabular}{|c|c|c|c|c|c|}
\hline \multirow{2}{*}{ Year } & \multicolumn{5}{|c|}{ Bud rot (Disease Incidence \%) } \\
\cline { 2 - 6 } & Coimbatore & Tirupur & Theni & Tirunelveli & Kanyakuamari \\
\hline $\mathbf{2 0 1 4 - 1 5}$ & 0.20 & 0.11 & 0.25 & 0.07 & 0.06 \\
\hline $\mathbf{2 0 1 5 - 1 6}$ & 0.96 & 1.40 & 0.37 & 0.17 & 0.08 \\
\hline $\mathbf{2 0 1 6 - 1 7}$ & 0.02 & 0.21 & 0.28 & 0.04 & 0.03 \\
\hline $\mathbf{2 0 1 7 - 1 8}$ & 0.01 & 0.12 & 0.15 & 0.05 & 0.04 \\
\hline $\mathbf{2 0 1 8 - 1 9}$ & 1.01 & 0.93 & 0.57 & 0.23 & 0.31 \\
\hline
\end{tabular}


Fig.1

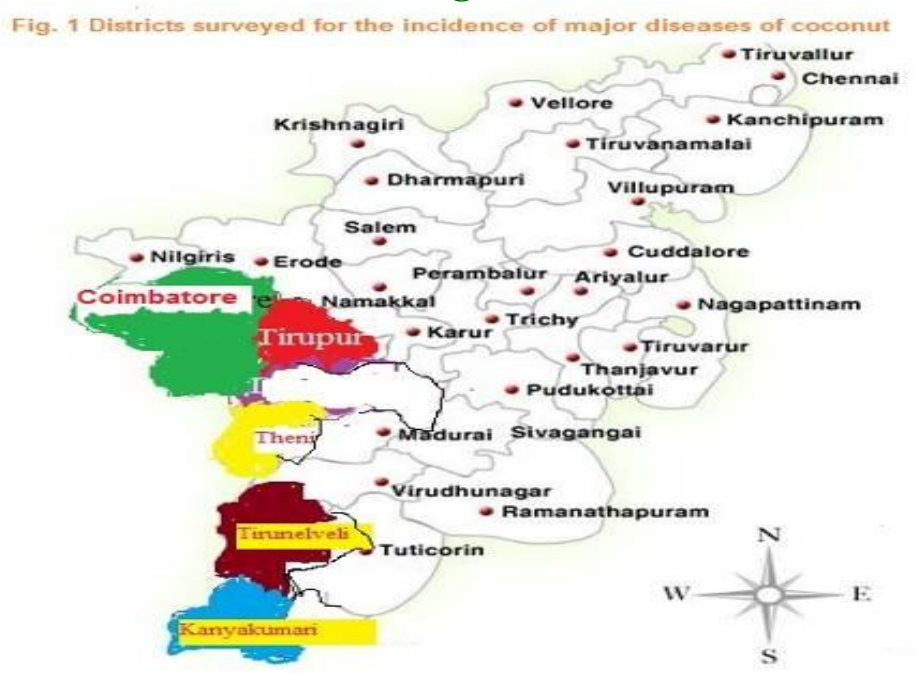

Table.3 Incidence of coconut basal stem rot in different districts of Tamil Nadu

\begin{tabular}{|c|c|c|c|c|c|}
\hline \multirow{2}{*}{ Year } & \multicolumn{5}{|c|}{ Basal stem rot (Disease Incidence \%) } \\
\cline { 2 - 6 } & Coimbatore & Tirupur & Theni & Tirunelveli & Kanyakuamari \\
\hline $\mathbf{2 0 1 4 - 1 5}$ & 1.29 & 2.59 & 0.50 & 0.15 & 0.65 \\
\hline $\mathbf{2 0 1 5 - 1 6}$ & 0.96 & 1.40 & 0.11 & 0.23 & 0.93 \\
\hline $\mathbf{2 0 1 6 - 1 7}$ & 0.54 & 0.99 & 0.30 & 0.23 & 0.16 \\
\hline $\mathbf{2 0 1 7 - 1 8}$ & 0.25 & 1.00 & 0.25 & 0.11 & 0.73 \\
\hline $\mathbf{2 0 1 8}-19$ & 1.45 & 1.19 & 0.34 & 0.34 & 1.45 \\
\hline
\end{tabular}

Table.4 Incidence of coconut stem bleeding in different districts of Tamil Nadu

\begin{tabular}{|l|c|c|c|c|c|}
\hline \multirow{2}{*}{ Year } & \multicolumn{5}{|c|}{ Stem bleeding (Disease Incidence \%) } \\
\cline { 2 - 6 } & Coimbatore & Tirupur & Theni & Tirunelveli & Kanyakuamari \\
\hline $\mathbf{2 0 1 4 - 1 5}$ & $\mathbf{0 . 1 8}$ & $\mathbf{0 . 4 8}$ & $\mathbf{0 . 0 5}$ & $\mathbf{0 . 0 3}$ & $\mathbf{0 . 0 1}$ \\
\hline $\mathbf{2 0 1 5 - 1 6}$ & 0.11 & 4.94 & 0.07 & 0.12 & 0.04 \\
\hline $\mathbf{2 0 1 6 - 1 7}$ & 0.07 & 0.16 & 0.06 & 0.04 & 0.17 \\
\hline $\mathbf{2 0 1 7 - 1 8}$ & 0.05 & 4.09 & 0.07 & 0.05 & 0.03 \\
\hline $\mathbf{2 0 1 8 - 1 9}$ & 0.26 & 0.30 & 0.14 & 0.08 & 0.79 \\
\hline
\end{tabular}

Table.5 State average for the incidence of major diseases of coconut

\begin{tabular}{|l|c|c|c|c|c|c|}
\hline Year & $\begin{array}{c}\text { Bud rot } \\
(\mathbf{\%})\end{array}$ & $\begin{array}{c}\text { Basal stem } \\
\text { rot (\%) }\end{array}$ & $\begin{array}{c}\text { Stem } \\
\text { bleeding (\%) }\end{array}$ & $\begin{array}{c}\text { Leaf blight } \\
\text { (PDI) }\end{array}$ & $\begin{array}{c}\text { Leaf spot } \\
\text { (pdi) }\end{array}$ & $\begin{array}{c}\text { Root } \\
\text { (wilt) }\end{array}$ \\
\hline $\mathbf{2 0 1 4 - 1 5}$ & 0.13 & 1.03 & 0.15 & 8.56 & 2.55 & 5.64 \\
\hline $\mathbf{2 0 1 5 - 1 6}$ & 0.59 & 0.72 & 1.05 & 4.86 & 2.86 & 10.39 \\
\hline $\mathbf{2 0 1 6 - 1 7}$ & 0.09 & 0.44 & 0.10 & 5.38 & 3.92 & 7.96 \\
\hline $\mathbf{2 0 1 7 - 1 8}$ & 0.07 & 0.46 & 0.88 & 4.90 & 3.65 & 5.79 \\
\hline $\mathbf{2 0 1 8 - 1 9}$ & 0.61 & 0.95 & 0.28 & 7.23 & 6.25 & 8.24 \\
\hline
\end{tabular}


Fig.2 Symptoms of bud rot

a .Brown discolouration of heart leaf

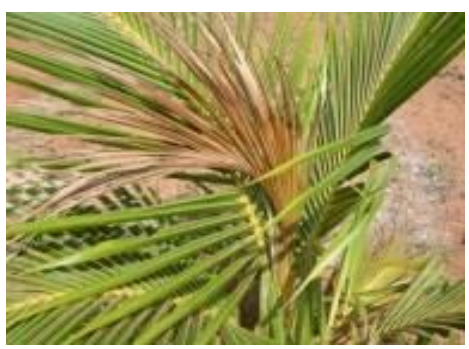

c. White fungal growth on infected portion

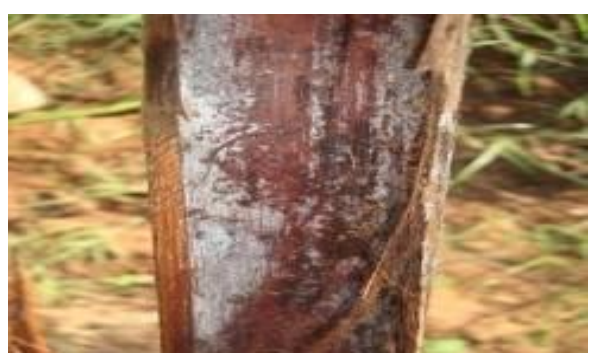

b.Rotting of central shoot

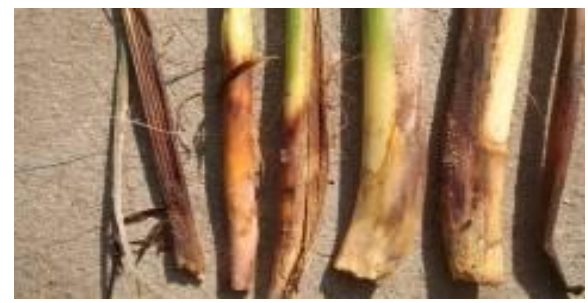

d. Secondary infection by larvea

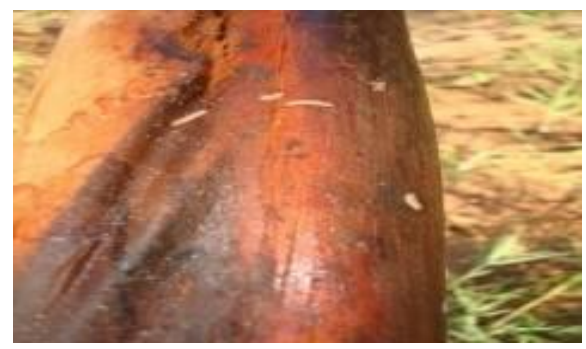

Fig.3 Symptoms of basal stem rot

a. Hanging of fronds

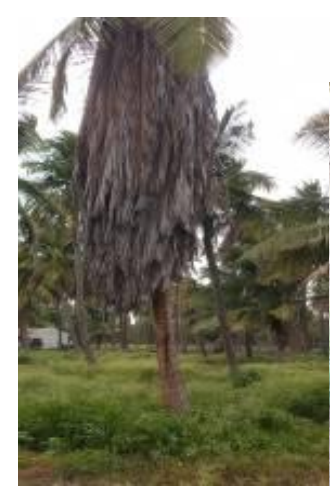

b.Bleeding patches on the base of the trunk
c.Formation of bracket
d.Decapitated stem

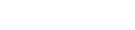

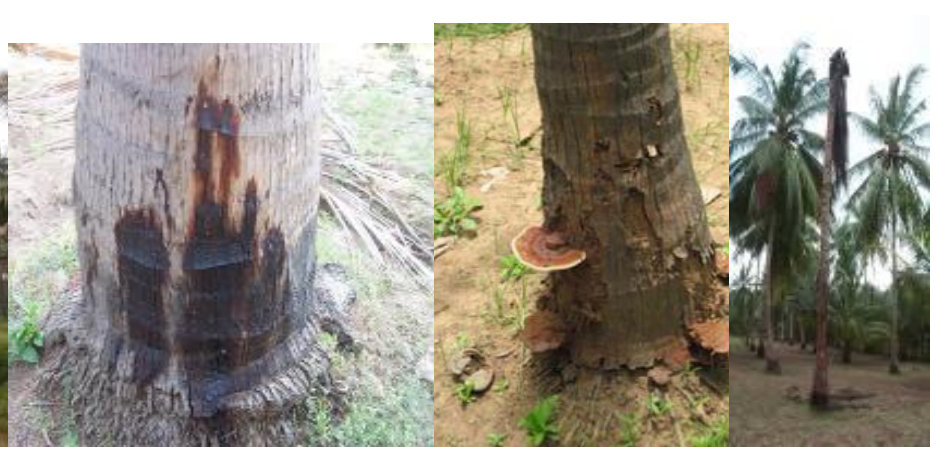

Fig.4 Symptoms of stem bleeding

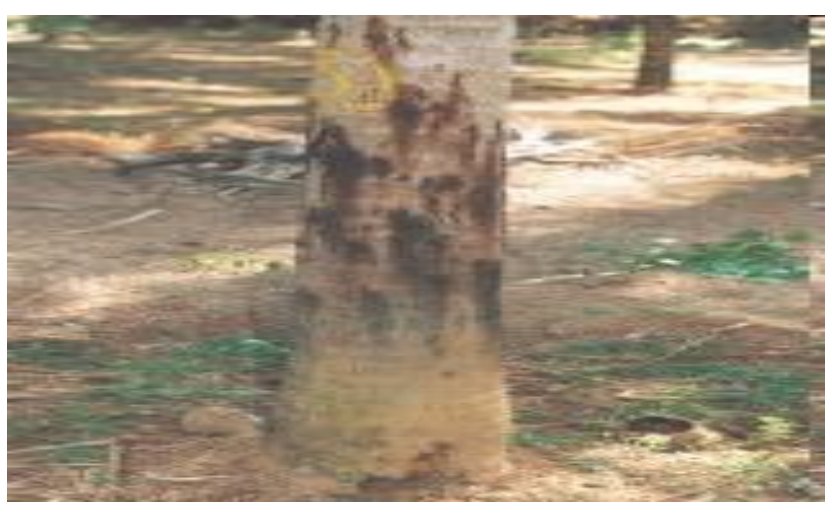


Fig.5 Symptoms of leaf blight

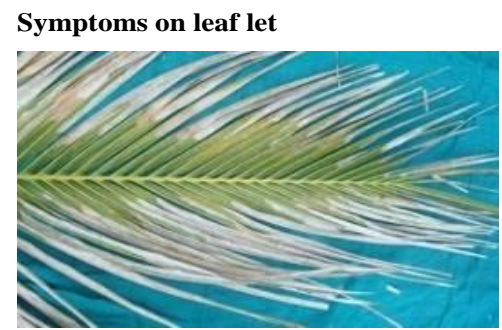

Symptoms on tree

Fig.6 Symptoms of leaf spot
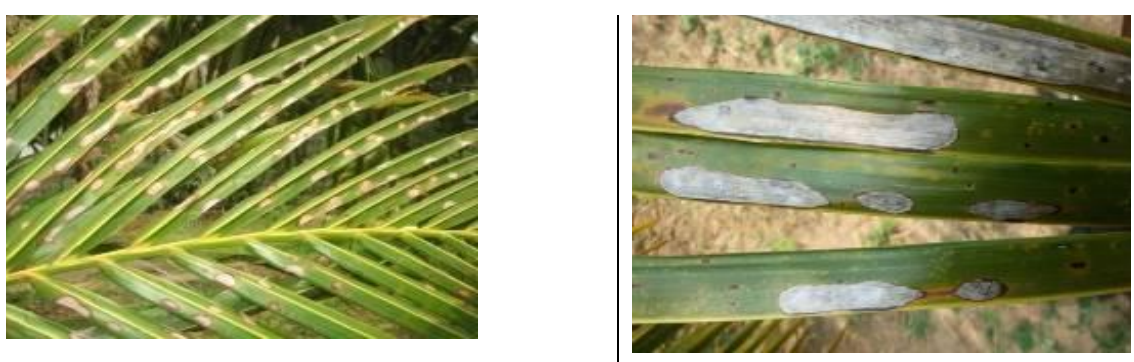

Fig.7 Symptoms of leaf spot
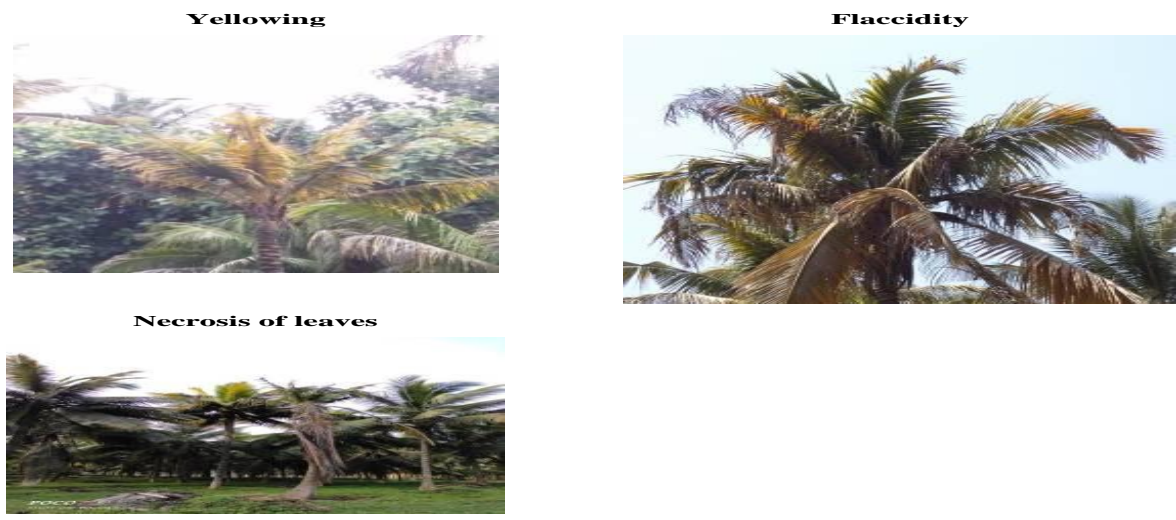

Fig.8 Incidence of coconut leaf blight in different districts of Tamil Nadu

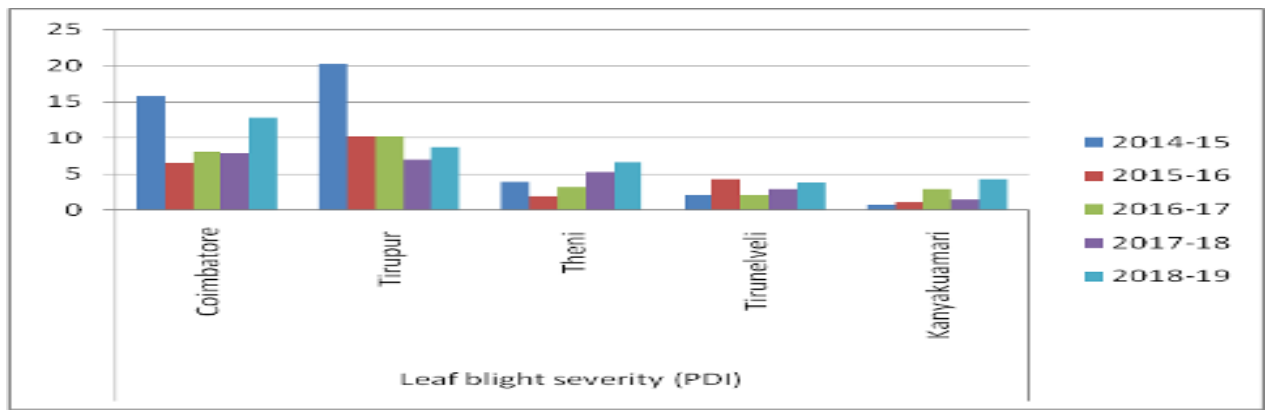


Fig.9 Incidence of coconut leaf spot in different districts of Tamil Nadu

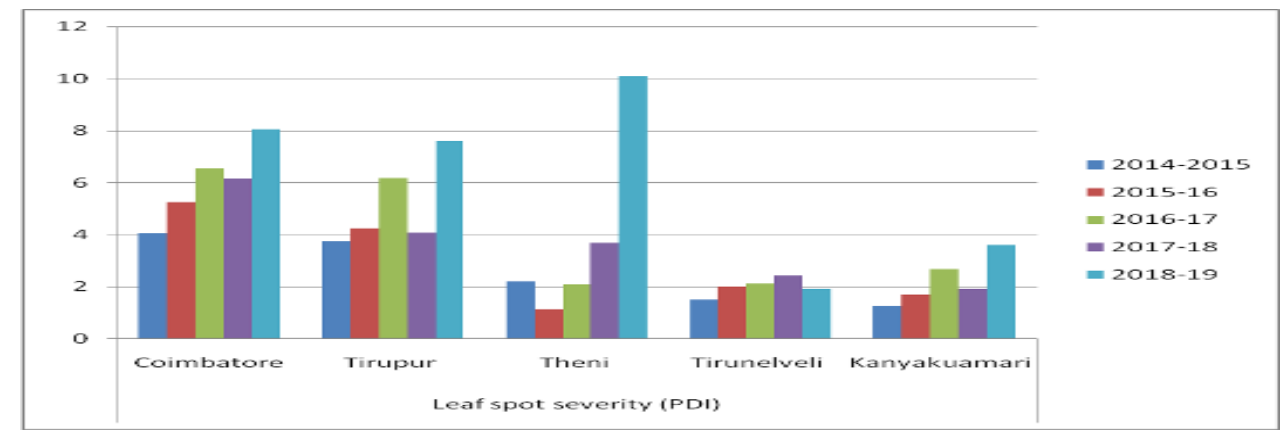

Fig.10 Incidence of coconut root (wilt) in different districts of Tamil Nadu

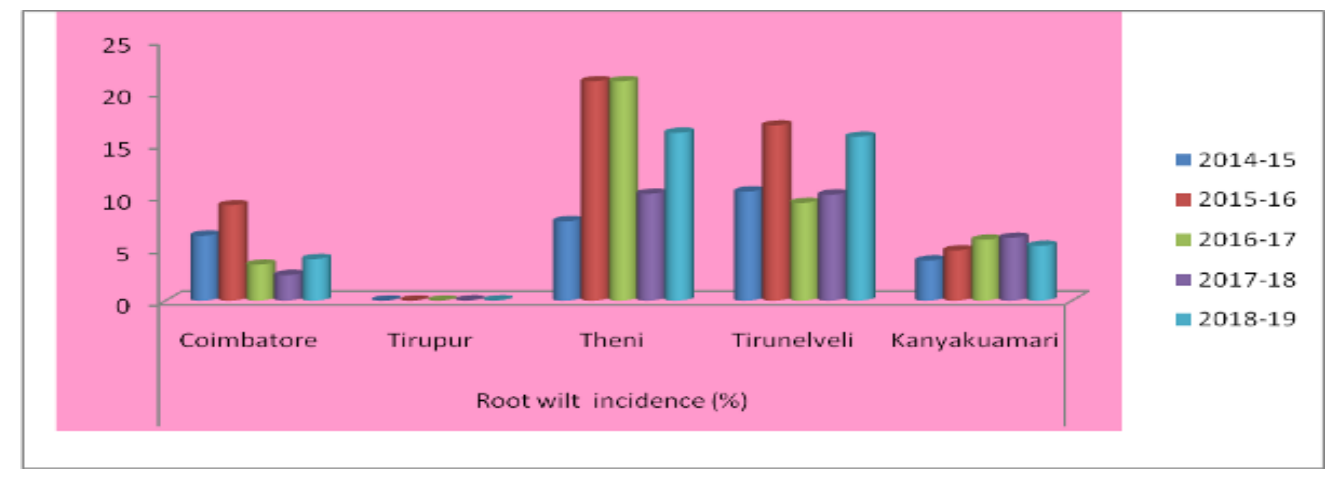

\section{Leaf spot}

The leaf spot caused by Pestalotiopis palmarum produced greyish white spots with dark brown margins with a yellow halo surrounded by a greyish margin. Sever infection resulted in complete drying of fronds (Figure 6).

The leaf spot infection in coconut plantation was observed in all the surveyed villages and the severity of the was disease was more in dwarf varieties compared to tall varieties. The villages viz., Avalchinnampalayam, Angalakuruchi and Kalliyapuram of Coimbatore districts showed the highest disease incidence (Table.1) The district average of the disease in Coimbatore, Tirupur and Theni ranged from $4.05-8.05,3.75-7.6$ 0 and $1.14-10.1$ PDI respectively (Figure 9).The highest state average of 6.2 PDI was registered during 2018 - 19 and it was 2.55
PDI during 2014 - 15 (Table 5). The occurrence of leaf blight in coconut plantation has been earlier reported from Andaman Islands (Rao, 1988), USA (Florida) Jamaica (Farr et al., 1989) Australia, Philippines and the Seychelles (Uchida and Aragaki, 1991).K. Athira. (2017) reported that the incidence of grey leaf blight is noticed in south farm. The most favorable condition for this pathogen is well drained soils or soils with potash deficiency, continuous rainy weather for4-5 days and strong winds.

\section{Root (wilt)}

The disease is incited by Candidatus Phytoplasma and transmitted through transmitted by plant hopper (Proutista moesta) and lace wing bug (Stephanitis typicus) The characteristic symptoms are flaccidity" of leaves i.e. they curve abnormally inwards, resembling the ribs of 
mammals Wilting of leaves from middle whorl to outward. Shedding of buttons and immature nuts occur. The older roots cracks and blotches and cortex turns brownish black resulting in drying in flakes (Figure 7a,b,c).

In all the five years of survey the highest root (wilt) incidence was recorded in Gudalore village, Cumbum block, Theni district (Table 1) and other villages viz., Samiandipudur, Maninagaram and Angorepalayam village also found to have more conducive environment for root(wilt).In Tirunelveli district the severity of root(wilt) was high in villages viz., Panboli, Kanakkapadivalasu, Thenpotahi and Meenashipuram. The highest district average of root (wilt) incidence was recorded in Tirunelveli district during 201415 remaining four years of disease assessment the disease incidence was found to be more in Theni district (Figure10). The analysis of state average revealed that the mean incidence of root(wilt)was 5.65 per cent during 2014- 15 and 8.24 per cent during 2018 -19 (Table 5). The results are in line with findings of Ramjegathesh et al., (2018) who found maximum incidence of the disease in Gudalur villageof Cumbum block in Theni district

This investigation could be useful to gain knowledge on occurrence and distribution of major diseases of coconut, to understand the spatial distribution of the disease and develop effective management strategy for diseases to prevent the lossess caused by the disease.

\section{References}

Bhaskaran, R., Ramanathan. T. 1984. Occurrence and spread of Thanjavur wilt disease of coconut. Indian Coconut Journal.15: 12-14.

CDB.2018. Coconut Statistics 2017-18. Coconut Development Board, India http://www.coconutboard.gov.in/present ation/ statistics
Chandra Mohanan, R., Abraham, K., Mathew, M. T., Nair, P. 2008.Status of bud rot disease of coconut in Calicut district and remedial measures to manage the disease. Report submitted to ICAR, New Delhi. Central Plantation Crops Research Institute, Kasaragod. 46p.

Chandran, K.P., Thamban, C., Prathibha, V.H.,Prathibha, P.S. 2017. Assessing status of pests and diseases with cluster approach - A case of coconut in Kasaragod district in northern Kerala. Journal of Plantation Crops, 2017, 45(1):33-42

Farr, D. F., Bills, G. F., Chamuris, G. P., Rossman, A. Y. 1989.Fungi on Plants and Plant Products in the United States. St. Paul, Minnesota, USA, APS Press

Henry Louis I. 2002. Coconut - The Wonder Palm, pp. 206-18.Hi-Tech Corporation Ramanputhoor, Nagercoil.

Johnson, I., Meena, B.,Rajamanickam, K. 2014. Biological management of leaf blight disease of coconut using rhizosphere microbes. J. Plantation Crops (India).42: 364-369.

Johnson,I., Ramjegathesh, R., Sheela, J., Shoba, N. and Maheshwarappa, H.P. 2017. Development of microbial consortia for the management of leaf blight disease of coconut. Acta Phytopathol. Entomol. Hungarica.52: 1-14.

Nambiar, K.K.N., Sastry K. RC. 1988. Stem bleeding disease of coconut: reproduction of symptoms by inoculation with Thielaviopsis paradoxa. Journal of Plantation Crops 14:130-133.

Nambiar, K.K.N., Rawther, T.S.S. 1993. Fungal disease of coconut in the world. In; Nair, M.K. et al.(Eds) Advances in Coconut Research and Development. Oxford and IBH. Publishing House., New Delhi pp 546-561.519-29

Nambiar, K.K.N.1994. Diseases and disorders 
of coconuts. In: Advances in Horticulture

Peter, P. K. and ChandraMohanan, R. 2009. Bud rot disease of coconut somepoints to ponder. Indian Coconut J. 51: 15-19.

Ramjegathesh, R., Johnson, I., Srinivasan, T., Maheswarappa, H.P., Shoba, N. 2018. Occurrence and management of coconut root (wilt) disease in Tamil Nadu, India. Phytopathogenic Mollicutes. 8: 40-45.

Ramjegathesh, R., Rajeswari, E., Venkatesan, K., MerinBabu., Maheswarappa H.P. 2019. Identification and confirmation of hotspot areas and management of root (wilt) disease in coconut. Phytopathogenic Mollicutes.9 : 265 272.

Rao, S. C. 1988. Leaf Spot disease of coconut incited by Bipolarisin curvata (Bernad) lcorn. Current Science 57: 674-675

Sharadraj K M and R.ChandraMohanan.2013.Status of Bud Rot Disease of Coconut in Endemic Areas of Southern States of India. Global Journal of Applied Agricultural Research.3(2): 56-61
Snehalatharani, A., Devappa, V., Rajappan, K., Maheswarappa H P. 2014a. Coconut basal stem rot is manageable. Indian Horticulture 59: 37-38.

Snehalatharani, A., Maheswarappa. H.P., Devappa, V., Malhotra,S. 2016.Status of coconut basal stem rot disease in India - A review Indian Journal of Agricultural Sciences.86 : 1519- 1529

Srinivasulu, B., Aruna, K., Sabitha Doraisamy., Rao, D. V. R.2001a. Occurrence and biocontrol of Ganoderma wilt disease of coconut in coastal agro ecosystem of AP. Journal of Indian Society for Coastal Agriculture Research 19: 191-195.

Sulladmath, V.V., Shantappa., P.B. 1980. Aetiology of stem bleeding disease of coconut in semi-dry tract of Karnataka. Current Research, 9:73-75.

Uchida, J. Y., Aragaki, M. 1991. Bipolaris and Exserohilum leaf spots. In: Chase AR, Broschat TK, eds. Diseases and Disorders of Ornamental Palms. St Paul, MN, USA: APS Press, 55.

\section{How to cite this article:}

Rajeswari, E., R. Ramjegathesh, V. Sivakumar, S. Praneetha, L. Pugalendhi and Maheswarappa, H. P. 2020. Occurrence and Distribution of Coconut Diseases in Tamil Nadu, India. Int.J.Curr.Microbiol.App.Sci. 9(10): 3859-3869. doi: https://doi.org/10.20546/ijcmas.2020.910.444 